Ambiente \& Água - An Interdisciplinary Journal of Applied Science
ISSN 1980-993X - doi:10.4136/1980-993X
www.ambi-agua.net
E-mail: ambi.agua@gmail.com

\title{
Self-assembly modification of polyamide membrane by coating titanium dioxide nanoparticles for water treatment applications
}

\author{
ARTICLES doi:10.4136/ambi-agua.2297
}

Received: 09 Jul. 2018; Accepted: 19 Feb. 2019

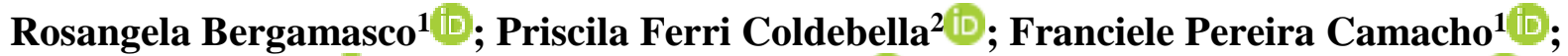 \\ Driano Rezende ${ }^{1}$; Natalia Ueda Yamaguchi ${ }^{3 *}$; Márcia Regina Fagundes Klen ${ }^{4}$; \\ Carlos José Macedo Tavares ${ }^{5}$; Maria Teresa Sousa Pessoa Amorim6 ${ }^{6}$; \\ ${ }^{1}$ Universidade Estadual de Maringá (UEM), Maringá, PR, Brasil \\ Departamento de Engenharia Química (DEQ). E-mail: ro.bergamasco@ hotmail.com, \\ franciele_camacho@hotmail.com,drirezend@gmail.com \\ ${ }^{2}$ Centro Universitário Dinâmica das Cataratas (UDC), Foz do Iguaçu, PR, Brasil \\ Colegiado de Farmácia. E-mail: pricoldebella@gmail.com \\ ${ }^{3}$ Centro Universitário de Maringá (Unicesumar/ICETI), Maringá, PR, Brasil \\ Departamento de Tecnologias Limpas. E-mail: nataliaueda@ hotmail.com \\ ${ }^{4}$ Universidade Estadual do Oeste do Paraná (UNIOESTE), Cascável, PR, Brasil \\ Centro de Engenharia e Ciências Exatas (CECE). E-mail: fagundes.klen@gmail.com \\ ${ }^{5}$ Universidade do Minho (UMinho), Guimarães, Portugal \\ Departamento de Física (DF). E-mail: ctavares@ fisica.uminho.pt \\ ${ }^{6}$ Universidade do Minho (UMinho), Guimarães, Portugal \\ Departamento de Engenharia Têxtil (DET). E-mail: mtamorim@det.uminho.pt \\ "Corresponding author
}

\begin{abstract}
This study modified the surface of a commercial polyamide membrane with the deposition of $\mathrm{TiO}_{2}$ nanoparticles by the self-assembly method under pressure with high permeability and photocatalytic activity. Changes in membrane characteristics and its performance for photocatalytic properties were evaluated. The results indicated that both membrane hydrophilicity and photocatalytic performance were significantly improved by the presence of $\mathrm{TiO}_{2}$ nanoparticles applied under a pressure of 1 bar. The deposition of the $\mathrm{TiO}_{2}$ particles under pressure was able to maintain the particles on the surface of the membranes and their photocatalytic capacity for three cycles of use. The prepared $\mathrm{TiO}_{2}$ photocatalytic membrane presented a great potential for wastewater treatment and for reuse wastewater systems due its ability to remove methylene blue (MB) dye solution by photocatalytic decomposition and physical separation.
\end{abstract}

Keywords: membrane filtration, methylene blue, organic photodegradation, photocatalysis, titanium dioxide.

\section{Modificação self-assembly de membrana de poliamida pela deposição de nanopartículas de dióxido titânio para aplicações no tratamento de água}

\section{RESUMO}

O principal objetivo do presente estudo foi modificar a superfície de uma membrana de poliamida comercial com a deposição de nanopartículas de $\mathrm{TiO}_{2}$ pelo método self-assembly 
sob pressão com alta permeabilidade e atividade fotocatalítica. Mudanças nas características da membrana e seu desempenho nas propriedades fotocatalíticas foram avaliados. Os resultados experimentais indicaram que tanto a hidrofilia da membrana quanto o desempenho fotocatalítico foram significativamente melhorados pela presença de nanopartículas de $\mathrm{TiO}_{2}$ aplicadas sob uma pressão de 1 bar. A deposição das partículas de $\mathrm{TiO}_{2}$ sob pressão foi capaz de manter as partículas na superfície das membranas e sua capacidade fotocatalítica por três ciclos de uso. A membrana fotocatalítica de $\mathrm{TiO}_{2}$ preparada apresentou um grande potencial no tratamento de efluentes e sistemas de reuso devido à sua capacidade de remover o corante azul de metileno por decomposição fotocatalítica e separação física.

Palavras-chave: azul de metileno, dióxido de titânio, filtração por membrana, fotocatálise, fotodegradação orgânica.

\section{INTRODUCTION}

In recent years, titanium dioxide $\left(\mathrm{TiO}_{2}\right)$ has become an important semiconductor used in various industrialized products, including sunscreens, inks, ointments, toothpastes, and catalysts. Due to its photocatalytic properties in comparison to other semiconductor composites such as $\mathrm{SiO}_{2}, \mathrm{ZnO}, \mathrm{Fe}_{2} \mathrm{O}_{3}, \mathrm{CuS}, \mathrm{Al}_{2} \mathrm{O}_{3}, \mathrm{ZrO}_{2}, \mathrm{TiO}_{2}$ has several advantages over their use in photocatalytic reactions, such as low cost due to its availability in nature, low toxicity, high chemical- and thermal stability and resistance to photocorrosion (Pan et al., 2013).

Given these characteristics, since the 1970's, when it was proved that water could be decomposed into hydrogen and oxygen in the presence of ultraviolet light on a $\mathrm{TiO}_{2}$ electrode in aqueous solution (Fujishima et al., 1975), $\mathrm{TiO}_{2}$ has received great attention for presenting photocatalytic properties for the decomposition of organic/inorganic materials. Thus the advanced oxidative processes (AOPs) through heterogeneous catalysis have been presented as an attractive processes for water and wastewater treatments.

However, the efficiency of $\mathrm{TiO}_{2}$ as a photocatalyst depends on several factors, such as the type of contaminant, the initial concentration of the organic contaminant, the amount and duration of radiant light on the $\mathrm{TiO}_{2}$ surface (Leong et al., 2014). In addition, heterogeneous photocatalysis is favored by the increase of the specific area of the semiconductors, therefore its effects are more positive when they are synthesized in nanometric dimensions.

$\mathrm{TiO}_{2}$ works as a catalyst; once organic matter has been degraded, $\mathrm{TiO}_{2}$ can be reused for a further catalysis process (LEONG et al., 2014). When $\mathrm{TiO}_{2}$ is used in suspension, it is very difficult to separate it from the treated water, hindering its practical application (Leong et al., 2014).

One of the most promising processes lies in the development of photocatalytic membranes, which are the combination of photocatalytic oxidation and membrane filtration. The advantage of this process is that two phenomena occur in a single treatment unit: the physical separation of the contaminant together with $\mathrm{TiO}_{2}$ adhered to the membrane, as well as the organic photodegradation (Fischer et al., 2015).

Once the pollutants are retained on the surface of the membrane, $\mathrm{TiO}_{2}$ under $\mathrm{UV}$ radiation can degrade the pollutants, preventing the formation of a layer of cake on the surface of the membrane, thus reducing pore blockage, and drastically reducing the concentration of pollutants, consequently improving the quality of the permeate (Leong et al., 2014).

You et al. (2012) and Shao et al. (2017) evaluated membranes modified with $\mathrm{TiO}_{2}$ nanoparticles and verified that $\mathrm{TiO}_{2}$ composite membranes showed better hydrophilicity, antifouling property and long-term flow stability.

This study proposes the deposition of $\mathrm{TiO}_{2}$ nanoparticles on the surface of a polyamide commercial membrane using the self-assembly method under pressure to enable enhanced 
photocatalytic properties under UV light. This study examines $\mathrm{TiO}_{2}$-polyamide membrane properties by various characterization techniques, its permeability in water and photocatalytic activity for MB dye solution.

\section{MATERIALS AND METHODS}

\subsection{Membrane modification}

The characteristics of the commercial polyamide membrane of nanofiltration (Model TS80, flat sheet nanofiltration membrane, $47 \mathrm{~mm}$ size, TriSep ${ }^{\mathrm{TM}}$, Sterlitech, Kent, WA, USA) used in this study were supplied by the manufacturer and are presented in Table 1.

Table 1. Commercial membrane characteristics.

\begin{tabular}{lc}
\hline Maximum Operating Pressure & $41 \mathrm{bar}$ \\
Maximum Operating Temperature & $45^{\circ} \mathrm{C} 1.0-12.0$ \\
Cleaning pH Range & $<0.1 \mathrm{ppm}$ \\
Chlorine Tolerance & 1 bar per element \\
Maximum Pressure Drop & 4 bar per housing \\
Maximum Silt density index & 5.0 \\
Maximum Turbidity & $1 \mathrm{NTU}$ \\
\hline
\end{tabular}

An innovative simple method was used to impregnate $\mathrm{TiO}_{2}$ in a commercial membrane. In this method, the nanofiltration system itself was used to perform the impregnation process. The self-assembly method was used for membrane modification; the methodology was adapted from Ngo et al. (2016) and Shao et al. (2017). In summary, a solution of $0.5 \%$ (w/v) of $\mathrm{TiO}_{2}$ nanoparticles was prepared in ultrapure water dispersion (Milli-Q® system, Millipore) under magnetic stirring for 1 hour followed by sonication for 1 hour at $37 \mathrm{KHz}$ frequency (Model Elmasonic P30H, Elma Schmidbauer Gmbh). The commercial polyamide membrane of nanofiltration was placed in contact with $30 \mathrm{~mL}$ of $\mathrm{TiO}_{2}$ solution under magnetic stirring and Nitrogen gas pressure at 1 bar for 90 minutes in a nanofiltration module (Model HP4750 StirredCell, Sterlitech (C), USA (Figure 1). After removal of the filtration module, the membrane was washed with ultrapure water under gentle stirring three times. The coated $\mathrm{TiO}_{2}$ membranes were maintained in ultrapure water until used for characterization and filtration tests. Before the characterization tests the membranes were dried at $37^{\circ} \mathrm{C}$ for 24 hours and stored in a desiccator. To evaluate the reproducibility of the membrane modification process, 9 membranes were prepared: 3 membranes were separated for characterization studies, 3 membranes for permeability studies and 3 membranes for the photocatalytic activity evaluation.

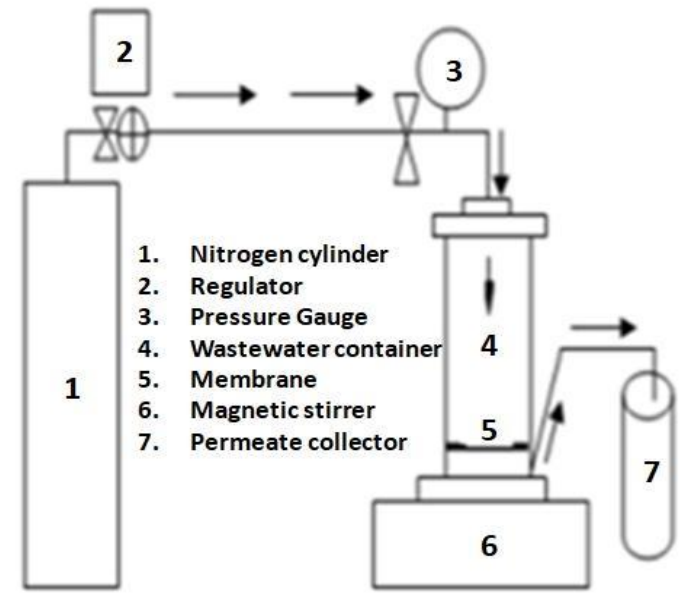

Figure 1. Nanofiltration module scheme 


\subsection{Membrane characterization}

The morphological characteristics of the membranes were analyzed in a scanning electron microscope, Model SS 550 Superscan (Shimadzu, Japan), covering the samples with a thin layer of $\mathrm{Au}$ at a voltage of $20 \mathrm{kV}$.

Membrane functional groups were analyzed by attenuated total reflectance infrared (ATRIR) spectroscopy, equipment Model Avatar 360 (ThermoNicolet). The spectral range was 4000 to $600 \mathrm{~cm}^{-1}$. ATR-IR spectra were obtained after 32 scans with a resolution of $4 \mathrm{~cm}^{-1}$. Measurements were performed at room temperature.

Differential Scanning Calorimetry (DSC) measurements were performed on MettlerToledo DSC28e equipment at a heating rate of $10^{\circ} \mathrm{C} \mathrm{min}^{-1}$, placing small pieces taken from the central region of the membrane in $40 \mu \mathrm{L}$ aluminium containers. All assays were performed using nitrogen as purge gas. Samples were exposed to heating at a rate of $10^{\circ} \mathrm{C} \mathrm{min}^{-1}$, from 25 to $300^{\circ} \mathrm{C}$.

Membranes samples (treated and untreated) were subjected to contact angle measurements to characterize their hydrophilicity/hydrophobicity. For this purpose, the Goniometer System OCA-15 was used, with SCA 20 software and CCD camera to record the image of the drop of distilled water on the sample. The tests were carried out under controlled environmental conditions at $19.3^{\circ} \mathrm{C}$ temperature. The volume of the water droplets used was $5 \mu \mathrm{L}$ and at the rate of $5 \mu \mathrm{L} / \mathrm{s}$. Five measurements were made at different points of the material, and the arithmetic mean was calculated. The behavior of the drop on the material as a function of time was also evaluated.

\subsection{Photocatalytic activity}

To evaluate the photocatalytic activity of $\mathrm{TiO}_{2}$ impregnated in the membrane under UV radiation, a solution of the organic dye MB was used. The assays were performed with a $1.7 \times 2.7 \mathrm{~cm}$ plate membrane $\left(4.59 \mathrm{~cm}^{2}\right.$ area $)$ placed in a quartz cell $(40 \mathrm{~mm} \times 40 \mathrm{~mm} \times 10 \mathrm{~mm})$, filled with $\mathrm{MB}$ solution $\left(13 \mathrm{~mL}, 10^{-2} \mathrm{mM}, \mathrm{pH}=6.8\right)$.

The membrane immersed in MB solution was initially held in the chamber for 30 minutes for adsorption/desorption until equilibrium of the concentration of MB solution was reached. The quartz cell was then irradiated with a high power LED lamp (Thorlabs, $700 \mathrm{~mA}$ ) with a peak excitation at $365 \mathrm{~nm}$ (UV-A). The radiation incident on the membrane was measured with a light intensity meter and the mean radiation value was approximately $4 \mathrm{~mW} . \mathrm{cm}^{2}$ (Marques et $a l ., 2013)$. The absorbance of the MB solution was monitored at 2-minute time intervals using a spectrophotometer (ScanSpec UV-Vis, ScanSci) with a wavelength scan of 300 to $900 \mathrm{~nm}$. The photodegradation rate of the AM solution was analyzed by monitoring the peak energy absorption intensity at $662 \mathrm{~nm}$.

The degradation reaction rate of the MB solution was calculated using the LangmuirHinshelwood model for pseudo-first-order reaction, expressed in Equation 1 (Yu et al., 2007):

$$
\ln \left(\frac{C}{C_{0}}\right)=-k t
$$

Where $\mathrm{C}_{0}$ represents the concentration of the dye $\mathrm{MB}$ at time $0, C$ is the concentration of the dye $\mathrm{MB}$ at time $\mathrm{t}$ and $k$ the first order constant of the reaction.

To evaluate the binding of the $\mathrm{TiO}_{2}$ nanoparticles to the membrane surface, the photocatalytic assay was repeated 3 times with the same sample, intercalated by washing the membrane with water for 10 minutes under slow stirring (Fischer et al., 2015). 


\subsection{Permeability experiments}

The permeability experiments were performed in a "dead-end" membrane filtration system, consisting of a $300 \mathrm{~cm}^{3}$ cylindrical steel cell, Model HP4750 StirredCell, Sterlitech (C) (USA), with a magnetic stirring system, connected to a cylinder of nitrogen gas, which has an effective filtration area of $12.254 \mathrm{~cm}^{2}$ (Figure 1). All experiments were performed at room temperature.

Water permeability was determined after the steady flow was reached (when the flow value remained constant for 30 minutes) at different applied pressures $(6,8,10,12$ and 14 bar). Initially, the membrane was compacted with ultrapure water at each pressure studied for $15 \mathrm{~min}$ (Ngo et al., 2016). The water flow was determined by Equation 2:

$J_{w}=\frac{V_{w}}{A \cdot t}$

Where $\mathrm{V}_{\mathrm{w}}$ is the ultrapure water volume (L) obtained by passing the membrane area $\mathrm{A}$ $\left(\mathrm{m}^{2}\right)$ at a filtration time of $\mathrm{t}(\mathrm{h})$.

The relation that governs the pure water flow to determine membrane permeability is (Ettori et al., 2011) (Equation 3):

$J_{w}=L_{w} \cdot \Delta P=\frac{1}{\mu R_{m}}$

Where $\mathrm{Jw}\left(\mathrm{L} \mathrm{h}^{-1} \mathrm{~m}^{-2}\right)$ is the flux of ultrapure water, Lw is the ultrapure water permeability $\left(\mathrm{L} \mathrm{h}^{-1} \mathrm{~m}^{-2}\right.$ bar $\left.^{-1}\right), \Delta \mathrm{P}$ is the applied pressure (bar), $\mu$ is the dynamic viscosity of the water $\left(1 \mathrm{~Pa} \mathrm{~s}^{-1}\right)$ and $\mathrm{Rm}$ is the hydraulic resistance of the membrane $\left(\mathrm{m}^{-1}\right)$.

\section{RESULTS AND DISCUSSION}

\subsection{Membrane characterization}

Figure 2 shows the comparison between the top surface images of the untreated membrane (A) and with self-assembled $\mathrm{TiO}_{2}(\mathrm{~B})$, respectively.
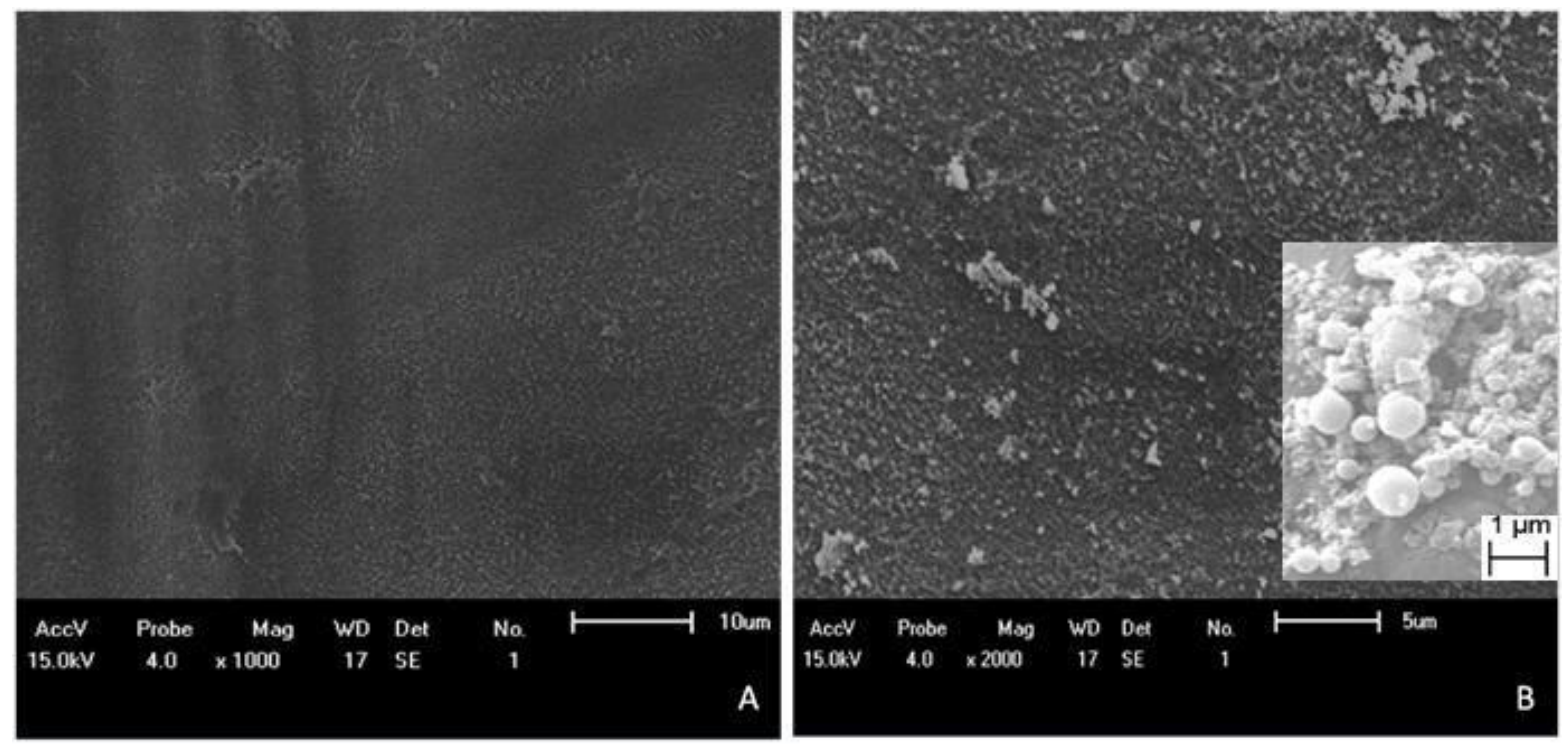

Figure 2. SEM images of the top surface of the untreated membrane (A) and with self-assembled $\mathrm{TiO}_{2}$ nanoparticles (B).

The original and $\mathrm{TiO}_{2}$-treated membrane when observed with naked eye has a smooth and flat surface; however, when increasing to a microscopic magnitude, a rough surface is observed 
(see Figure 2A). According to Xiaoxiao et al. (2016) the morphology of the polyamide layer is typically of the "ridge and valley" type.

When observing Figure $2 \mathrm{~B}$, the presence of clusters of nanoparticles distributed on the surface of the membrane, resulting from deposited $\mathrm{TiO}_{2}$ nanoparticles, is observed. The size differences of nanoparticles aggregated on the membrane surface are due to the sonication process of the colloidal solution of $\mathrm{TiO}_{2}$, in which larger aggregated particles of $\mathrm{TiO}_{2}$ were easily divided to form secondary particles from a few tens to a few hundred nanometers. In addition, at the time of deposition, the application of 1 bar pressure to the $\mathrm{TiO}_{2}$ solution on the membrane possibly helped the adhesion of the nanoparticles to their surface.

Although SEM analysis can demonstrate the presence of $\mathrm{TiO}_{2}$ nanoparticles on the membrane surface, differential scanning calorimetry was also performed. This analysis was able to identify the enthalpy change of the material when it undergoes physical and chemical changes. For monitoring variations in the behavior of chemical bonds that may have occurred due to the deposition of $\mathrm{TiO}_{2}$ on the surface of the polyamide polymer membrane, attenuated total reflectance infrared spectroscopy (ATR-IR) was used.

Figure 3A shows non-isothermal DSC thermograms obtained for the untreated and $\mathrm{TiO}_{2}$ treated membranes and Figure 3B shows the typical spectra of the original membrane (black solid line) and the $\mathrm{TiO}_{2}$ modified membrane (red solid line).
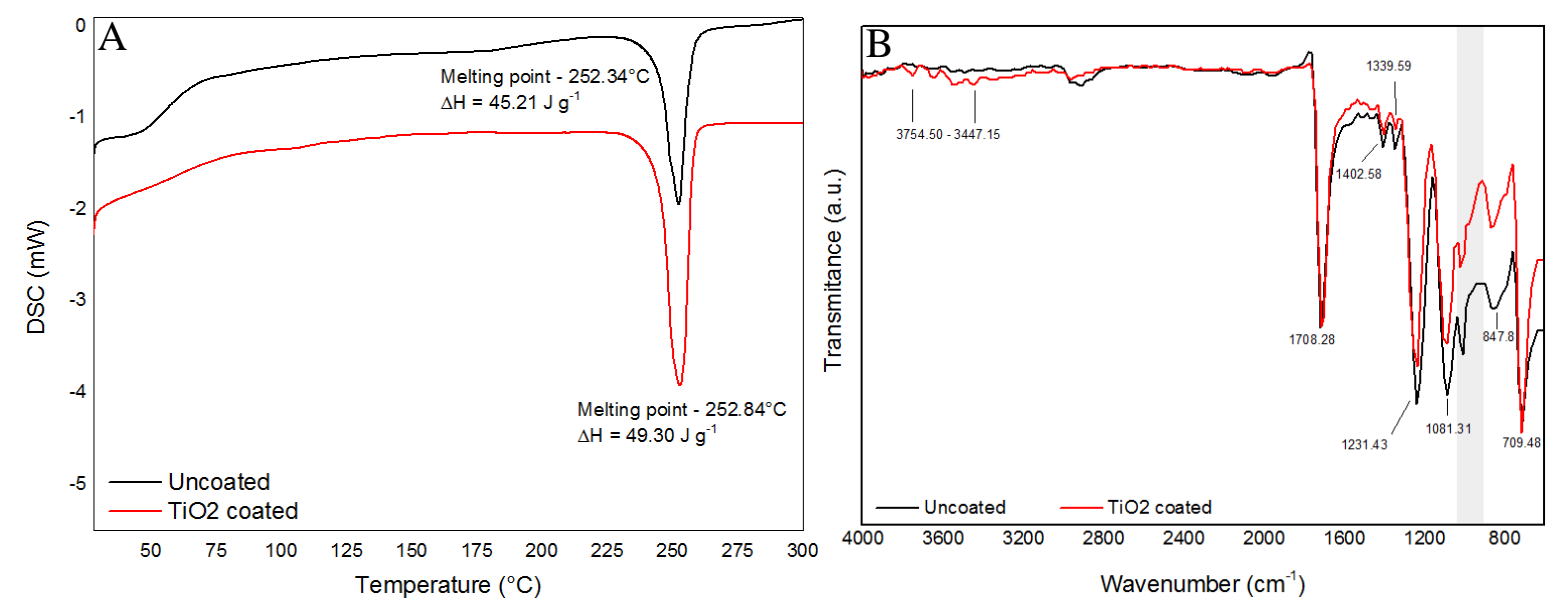

Figure 3. Thermograms of membranes untreated and treated with $\mathrm{TiO}_{2}$. (A) and ATR-IR spectrum of untreated and treated membrane (B).

It can be observed in Figure $3 \mathrm{~A}$ that the slope of the curve around $50^{\circ} \mathrm{C}$ for the treated membrane was not found, indicating the glassy transition state may have been affected by deposition of $\mathrm{TiO}_{2}$ on the surface of the membrane. The glass transition of the polymer membrane occurs at a temperature around $50^{\circ} \mathrm{C}$ (Cossich et al., 2015).

Comparing both curves of Figure $3 \mathrm{~A}$, the presence of an endothermic peak at $252.34^{\circ} \mathrm{C}$ for the untreated membrane and $252.84^{\circ} \mathrm{C}$ for the treated membrane is observed. This peak is associated with the melting process of the polymer. The presence of $\mathrm{TiO}_{2}$ probably altered the crystalline behavior of the polymer matrix, making it difficult to crystallize. This can be observed by the increase of energy required in the transformation process, which for the untreated membrane required $45.21 \mathrm{~J} \mathrm{~g}^{-1}$, and for the treated membrane, $49.30 \mathrm{~J} \mathrm{~g}^{-1}$ of energy was required, indicating that the presence of nanoparticles of $\mathrm{TiO}_{2}$ increases the thermal stability of the membrane.

It was observed in Figure 3B that what characterizes the polyamide surface of the untreated membrane are: the presence of the strong bands at $1708.28 \mathrm{~cm}^{-1}, 1231.43 \mathrm{~cm}^{-1}, 1081.31 \mathrm{~cm}^{-1}$, attributed to the stretching vibration of the amide II carbonyl, axial deformation vibrations of 
the $\mathrm{CN}$ bond and the NH bond stretching of amide I (Li et al., 2009). As the type of polyamide is aromatic, the ring can be detected by the vibration involving the elongation and contraction of carbon-carbon bonds in an aromatic ring at $1402.52 \mathrm{~cm}^{-1}$. Another strong band that characterizes the membrane can be seen at $847.8 \mathrm{~cm}^{-1}$ and $709.48 \mathrm{~cm}^{-1}$. According to Smith, such bands are caused by the out-of-plane C-H bond of an aromatic ring (Smith, 2016). Due to the planar aromatic rings, all hydrogens are in the plane of the molecule. When these hydrogens bend above and below the plane of the molecule, they are going through by the out-of-plane C$\mathrm{H}$ bond out of the plane, which is sometimes called a "wag" because of the resemblance of the vibration to the swish of a dog's tail.

Comparing to the $\mathrm{TiO}_{2}$-treated membrane in Figure 3B, it can be verified that the main bands were not altered, indicating that the polymer surface was not modified by the presence of $\mathrm{TiO}_{2}$; however, a small modification in the spectrum in the regions of $3754.50 \mathrm{~cm}^{-1}$ to $3447.15 \mathrm{~cm}^{-1}$ (referring to $\mathrm{OH}$ groups) and in the region of $986.42 \mathrm{~cm}^{-1}$ (gray ragged region). According to different authors, there is a possibility that the bands in the region $3754.50 \mathrm{~cm}^{-1}$ to $3447.15 \mathrm{~cm}^{-1}$ indicate the interaction of Ti-OH and that of $986.42 \mathrm{~cm}^{-1}$ is attributed to $\mathrm{Ti}-\mathrm{O}-\mathrm{Ti}$ or $\mathrm{C}=\mathrm{O}-\mathrm{Ti}$ bond, confirming the occurrence of deposition/interaction of $\mathrm{TiO}_{2}$ nanoparticles on the surface of the membrane (Ngo et al., 2016).

The presence of $\mathrm{OH}$ bonds in the membrane coated with $\mathrm{TiO}_{2}$ can lead to the hydrophilicity of the modified membrane, a characteristic that was proved by the analysis of the contact angle and permeability in water (Figure 4).
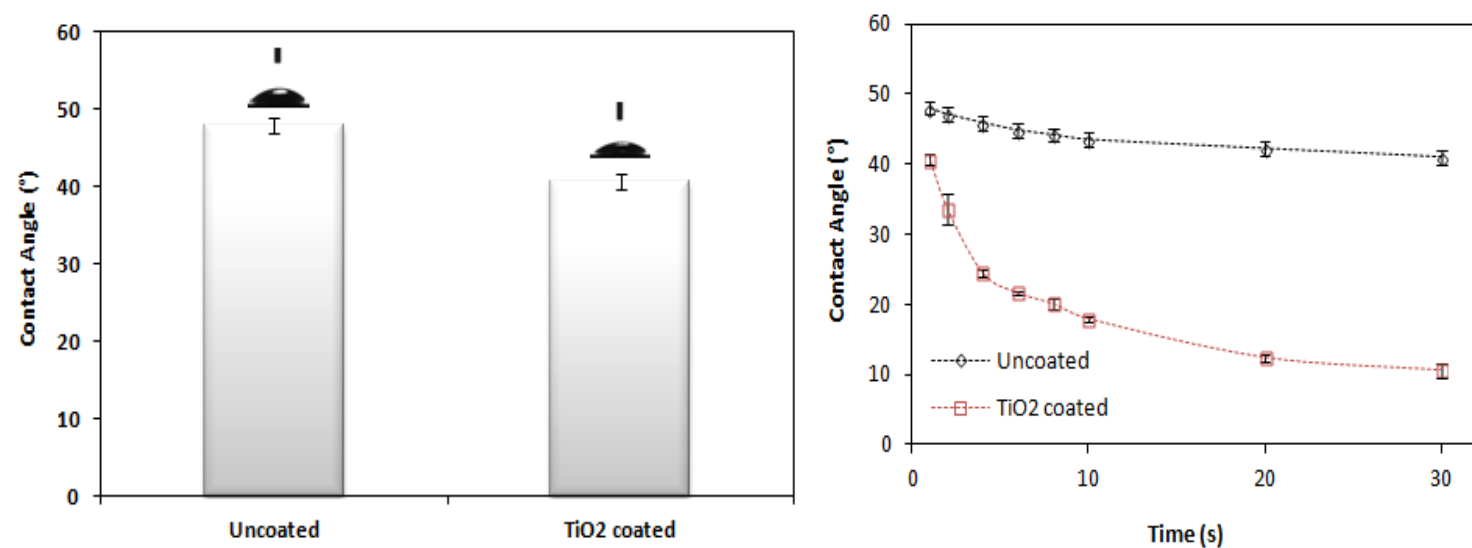

Figure 4. Contact angle between the membranes and ultrapure water droplet (A) and contact angle measurements as a function of time (B).

Surface hydrophilicity is one of the most important characteristics for a filtration membrane. One of the ways to obtain the relative hydrophilicity of the polymer membrane is the measurement of the contact angle (Li et al., 2009). The "sessile drop" method was performed to examine the hydrophilicity of the membrane surfaces. If a drop of water comes in contact with a hydrophilic material, it spreads across the surface, resulting in a contact angle of zero or less. The wettability of the material is characterized by the contact angle between the surface of the solid and the tangent to the surface of the liquid from the point of contact (Cheryan, 1998).

As can be seen in Figure 4A, the contact angle of the untreated membrane was $48.03^{\circ} \mathrm{C}$, which was slightly reduced to $40.64^{\circ} \mathrm{C}$ after the modification with $\mathrm{TiO}_{2}$ nanoparticles. This reduction can be explained by the deposition of $\mathrm{TiO}_{2}$ layer, making the surface area of the membrane more porous, facilitating the absorption of water and consequently increasing the hydrophilic property of the membrane (Verliefde et al., 2009; Yamashita et al., 2003).

To confirm the higher hydrophilicity of the $\mathrm{TiO}_{2}$ treated surfaces, the dynamic contact angle was evaluated. The contact angle measurement was determined every second for 30 seconds, and the results are shown in Figure 4B. 
The polyamide polymer leaves the membrane with hydrophilic characteristics; however we can see that the contact angles almost remain stable during the time of contact with the ultrapure water. For the membrane with $\mathrm{TiO}_{2}$, it was noted that the contact angle was gradually reduced within the measurement time. This can be explained by the fact that $\mathrm{TiO}_{2}$ has additional surface areas to absorb water more quickly and consequently leave the membrane more hydrophilic. The same behavior was observed by Li et al. (2009) and You et al. (2012) who evaluated Polyvinylidene fluoride membranes treated by self-assembly with $\mathrm{TiO}_{2}$; and by $\mathrm{Ngo}$ et al. (2016) who modified the surface of commercial polyamide nanomembranes with $\mathrm{TiO}_{2}$ nanoparticles.

\subsection{Photocatalytic activity}

The results obtained for the photodegradation of MB solution are presented in Figure 5.
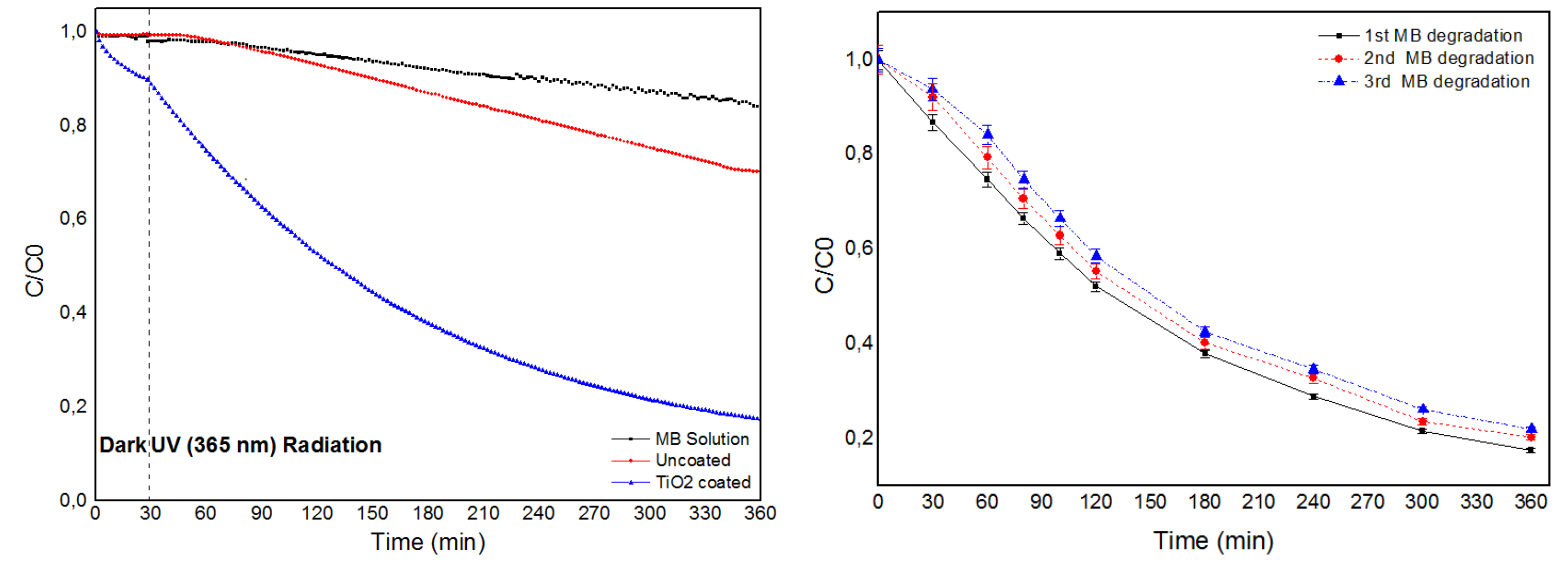

Figure 5. Degradation of MB (initial concentration $=10^{-2} \mathrm{mM}$ ) versus UV-A (A) and degradation of $\mathrm{MB}$ by 3 consecutive cycles with $\mathrm{TiO}_{2}$ treated membrane (B).

It can be observed that in the first 30 minutes, without radiation incidence, there was no significant change in the concentration of dye for both treated membrane and untreated membrane. The small reduction of the observed concentration $(\sim 10 \%$ removal $)$ is due to the presence of pores of the $\mathrm{TiO}_{2}$ nanoparticles in which the adsorption process occurs. These pores will lead to a higher surface area on the membrane surface and, consequently, to a greater coverage for the dye adsorption (Tavares et al., 2010).

The specific surface is one of the most important properties for photocatalytic activity, since photocatalytic reactions occur on the surface of the nanocatalyst. Thus, at the time of 30 minutes, in dark conditions, favours adsorption, exceeding the recombination fastness of the hole-electron pair (in nanoseconds), which usually results in excellent photocatalytic activities (Ochiai and Fujishima, 2012).

When analyzing the $\mathrm{MB}$ solution in contact with the $\mathrm{TiO}_{2}$-treated membrane, after 6 hours under UV irradiation, it was found that MB degradation was approximately $91 \%$. Table 1 shows the results of the photocatalytic assays of the MB solution in the presence and absence of the membranes (treated and untreated).

As can be observed, the of $\mathrm{TiO}_{2}$ clearly improves the photocatalytic activity, since it presented a higher reaction rate (4.6 times higher than using the untreated membrane), lower half-life and higher efficiency of dye degradation. The data found in this study showed a photocatalytic behavior that is compatible with those reported in the literature (Cossich et al., 2015; Li et al., 2007; Yamashita et al., 2003).

The mechanism of MB dye degradation may be explained by a adsorption-migrationphotodegradation process. In this process, MB is first adsorbed by the dense polymer film, then 
migrates to the $\mathrm{TiO}_{2}$ nanoparticles and it is finally degraded by the $\mathrm{TiO}_{2}$ catalyst under UV radiation (Cossich et al., 2015; He et al., 2009). Thus, the efficiency of the process is related to the combination of the membrane surface area (porosity) and the available $\mathrm{TiO}_{2}$ surface area (Fischer et al., 2014; Lombardi et al., 2011)

In addition, it was found that the solution of $\mathrm{MB}$ that was in contact with the $\mathrm{TiO}_{2}$ treated membrane had its color changed from bright blue to colorless during the photocatalysis process, indicating that an oxidation-reduction mechanism occurred on the surface of the thin films of titania, subsequently degrading the organic chromophore over time (Marques et al., 2010).

Once dye was degraded, it was intended to verify the reusability of the $\mathrm{TiO}_{2}$-treated membrane by repeating the MB photodegradation experiment for two more cycles, intercalated by washing the membrane with ultrapure water. The results can be seen in Figure 5B.

It was observed that the membrane treated with $\mathrm{TiO}_{2}$ showed photocatalytic activity during the three cycles of radiation. This result indicates that the catalyst is regenerated and also was not lost during the washes with water, demonstrating that the application of the pressure of 1 bar during the treatment had a positive effect on the deposition process of the $\mathrm{TiO}_{2}$ nanoparticles.

According to Fischer et al. (2015), the presence of $\mathrm{TiO}_{2}$ on the surface of the membrane still has protective action since it avoids damage to the polymer membrane due to direct incidence of UV radiation on its surface.

These results indicate that a self-cleaning property was created by the $\mathrm{TiO}_{2}$ particles deposited on the membrane surface (Madaeni and Ghaemi, 2007). This self-cleaning property can be explained both by the effect of increased membrane hydrophilicity, which may lead to a decrease in the hydrophobic interaction between the organic pollutants and the membrane surface (Bae and Tak, 2005), and by the photocatalytic effect under irradiation $\mathrm{UV}$, of the $\mathrm{TiO}_{2}$ particles in the decomposition of the pollutants.

\subsection{Permeability experiments}

Figure 6 shows the water flow changes caused by different pressures for the untreated and $\mathrm{TiO}_{2}$ treated membrane. The water permeability (Lw) of the membranes can be found by determining the coefficient obtained by the linear regression of the graph of the pure water flux $(\mathrm{JW})$ versus transmembrane pressure $(\Delta \mathrm{P})$.

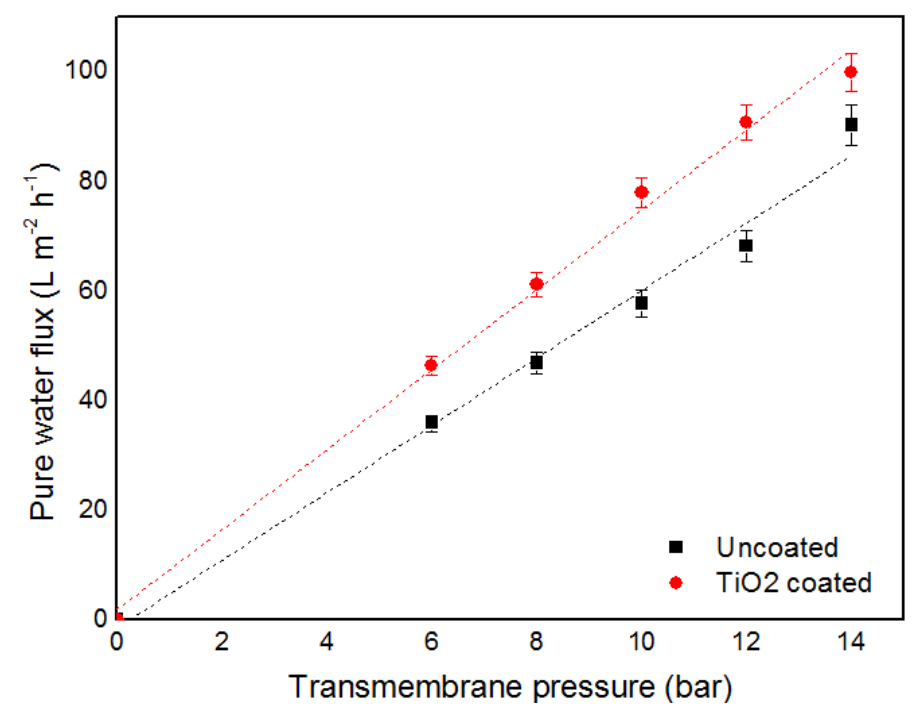

Figure 6. Variation of water flow at different pressures for untreated and $\mathrm{TiO}_{2}$ treated membranes. 
The nominal permeability of the membrane (supplied by the manufacturer) is $5.8 \mathrm{~L} \mathrm{~h}^{-1} \mathrm{~m}^{-2}$ barr $^{-1}$ however, the value obtained with the filtration module used was $6.15 \mathrm{~L} \mathrm{~h}^{-1} \mathrm{~m}^{-2}$ bar $^{-1}$. The $\mathrm{TiO}_{2}$ treated membrane presented a higher permeability of $7.28 \mathrm{~L} \mathrm{~h}^{-1} \mathrm{~m}^{-2} \mathrm{bar}^{-1}$, a result that corroborates with the results found in the contact angle analyses. The membrane becomes more hydrophilic with the presence of $\mathrm{TiO}_{2}$ nanoparticles on the surface; consequently, it presents a lower contact angle and a higher flow of water. Titanium dioxide has been the focus of numerous investigations in recent years, because its high hydrophilicity, stable chemical property, innocuity and low cost, etc. The use of $\mathrm{TiO}_{2}$ to increase the membrane hydrophilicity is observed by other researchers and is in accordance with the results founded in this study (Luo et al., 2005; Vatanpour et al., 2012).

\section{CONCLUSIONS}

The results of this study indicate that the impregnation of $\mathrm{TiO}_{2}$ particles on the surface of a polyamide membrane by self-assembly under pressure was successful. ATR-IR analysis confirmed that the deposition process does not significantly alter the chemical structure of the polymer matrix of polyamide. Measurements of contact angle, as well as the determination of permeability, demonstrated that the hydrophilicity of the membrane increased. The photocatalytic performance of the membrane when depositing $\mathrm{TiO}_{2}$ on surfaces has been improved, since the mechanism of degradation is established by the synergistic interaction of the $\mathrm{TiO}_{2}$-dye membrane surface and UV irradiation. It is a simple technique for effective removal of recalcitrants of organic matter, such as dyes, phenols and humic acids, and can be reached by the photocatalytic membrane under UV irradiation.

\section{ACKNOWLEDGEMENTS}

This work was supported by the Portuguese National Fund, through the FCT - Fundação para a Ciência e a Tecnologia, under the project UID/CTM/00264/2013 and CAPES Coordenação de Aperfeiçoamento Pessoal de Nível Superior - Agreement CAPES/FCT20142017. The authors thank the support of the researchers of surfaces laboratory of the Centre of Physics of the University of Minho, Portugal by the support analyzes.

\section{REFERENCES}

BAE, T.-H.; TAK, T.-M. Preparation of $\mathrm{TiO}_{2}$ self-assembled polymeric nanocomposite membranes and examination of their fouling mitigation effects in a membrane bioreactor system. Journal of Membrane Science, v. 266, n. 1-2, p. 1-5, 2005. https://doi.org/10.1016/j.memsci.2005.08.014

CHERYAN, M. Ultrafiltration and Microfiltration Handbook. Lancaster: Technomic, 1998. $264 \mathrm{p}$.

COSSICH, E.; BERGAMASCO, R.; DE AMORIM, M. P.; MARTINS, P.; MARQUES, J.; TAVARES, C. J.; LANCEROS-MÉNDEZ, S.; SENCADAS, V. Development of electrospun photocatalytic TiO 2-polyamide-12 nanocomposites. Materials Chemistry and Physics, v. 164, p. 91-97, 2015. https://doi.org/10.1016/j.matchemphys.2015.08.029

ETTORI, A.; GAUDICHET-MAURIN, E.; SCHROTTER, J.-C.; AIMAR, P.; CAUSSERAND, C. Permeability and chemical analysis of aromatic polyamide-based membranes exposed to sodium hypochlorite. Journal of Membrane Science, v. 375, n. 1, p. 220-230, 2011. https://doi.org/10.1016/j.memsci.2011.03.044 
FISCHER, K.; GLÄSER, R.; SCHULZE, A. Nanoneedle and nanotubular titanium dioxide PES mixed matrix membrane for photocatalysis. Applied Catalysis B: Environmental, v. 160-161, p. 456-464, 2014. https://doi.org/10.1016/j.apcatb.2014.05.054

FISCHER, K.; GRIMM, M.; MEYERS, J.; DIETRICH, C.; GLÄSER, R.; SCHULZE, A. Photoactive microfiltration membranes via directed synthesis of TiO 2 nanoparticles on the polymer surface for removal of drugs from water. Journal of Membrane Science, $v$. 478, p. 49-57, 2015. https://doi.org/10.1016/j.memsci.2015.01.009

FUJISHIMA, A.; KOHAYAKAWA, K.; HONDA, K. Hydrogen production under sunlight with an electrochemical photocell. Journal of the Electrochemical Society, v. 122, p. 1487-1489, 1975.

HE, T.; ZHOU, Z.; XU, W.; REN, F.; MA, H.; WANG, J. Preparation and photocatalysis of $\mathrm{TiO}_{2}$-fluoropolymer electrospun fiber nanocomposites. Polymer, v. 50, n. 13, p. 30313036, 2009. https://doi.org/10.1016/j.polymer.2009.04.015

LEONG, S.; RAZMJOU, A.; WANG, K.; HAPGOOD, K.; ZHANG, X.; WANG, H. TiO 2 based photocatalytic membranes: a review. Journal of Membrane Science, v. 472, p. 167-184, 2014. https://doi.org/10.1016/j.memsci.2014.08.016

LI, J.-B.; ZHU, J.-W.; ZHENG, M.-S. Morphologies and properties of poly (phthalazinone ether sulfone ketone) matrix ultrafiltration membranes with entrapped $\mathrm{TiO}_{2}$ nanoparticles. Journal of Applied Polymer Science, v. 103, n. 6, p. 3623-3629, 2007. https://doi.org/10.1002/app.25428

LI, J.-H.; XU, Y.-Y.; ZHU, L.-P.; WANG, J.-H.; DU, C.-H. Fabrication and characterization of a novel TiO 2 nanoparticle self-assembly membrane with improved fouling resistance. Journal of Membrane Science, v. 326, n. 2, p. 659-666, 2009. https://doi.org/10.1016/j.memsci.2008.10.049

LOMBARDI, M.; PALMERO, P.; SANGERMANO, M.; VARESANO, A. Electrospun polyamide-6 membranes containing titanium dioxide as photocatalyst. Polymer International, v. 60, n. 2, p. 234-239, 2011. https://doi.org/10.1002/pi.2932

LUO, M.-L.; ZHAO, J.-Q.; TANG, W.; PU, C.-S. Hydrophilic modification of poly (ether sulfone) ultrafiltration membrane surface by self-assembly of $\mathrm{TiO}_{2}$ nanoparticles. Applied Surface Science, v. 249, n. 1, p. 76-84, 2005. https://doi.org/10.1016/j.apsusc.2004.11.054

MADAENI, S.; GHAEMI, N. Characterization of self-cleaning RO membranes coated with TiO 2 particles under UV irradiation. Journal of Membrane Science, v. 303, n. 1, p. 221-233, 2007. https://doi.org/10.1016/j.memsci.2007.07.017

MARQUES, J.; OLIVEIRA, L.; PINTO, R.; COUTINHO, P. J.; PARPOT, P.; GÓIS, J.; COELHO, J.; MAGALHÃES, F.; TAVARES, C. Release of volatile compounds from polymeric microcapsules mediated by photocatalytic nanoparticles. International Journal of Photoenergy, v. 2013, 2013. http://dx.doi.org/10.1155/2013/712603

MARQUES, S.; TAVARES, C.; OLIVEIRA, L.; OLIVEIRA-CAMPOS, A. Photocatalytic degradation of CI Reactive Blue 19 with nitrogen-doped $\mathrm{TiO}_{2}$ catalysts thin films under UV/visible light. Journal of Molecular Structure, v. 983, n. 1-3, p. 147-152, 2010. https://doi.org/10.1016/j.molstruc.2010.08.044

Rev. Ambient. Água vol. 14 n. 3, e2297 - Taubaté 2019 
NGO, T. H. A.; NGUYEN, D. T.; DO, K. D.; NGUYEN, T. T. M.; MORI, S.; TRAN, D. T. Surface modification of polyamide thin film composite membrane by coating of titanium dioxide nanoparticles. Journal of Science: Advanced Materials and Devices, v. 1, n. 4, p. 468-475, 2016. https://doi.org/10.1016/j.jsamd.2016.10.002

OCHIAI, T.; FUJISHIMA, A. Photoelectrochemical properties of $\mathrm{TiO}_{2}$ photocatalyst and its applications for environmental purification. Journal of Photochemistry and Photobiology C: Photochemistry Reviews, v. 13, n. 4, p. 247-262, 2012. https://doi.org/10.1016/j.jphotochemrev.2012.07.001

PAN, X.; YANG, M.-Q.; FU, X.; ZHANG, N.; XU, Y.-J. Defective $\mathrm{TiO}_{2}$ with oxygen vacancies: synthesis, properties and photocatalytic applications. Nanoscale, v. 5, n. 9, p. 3601-3614, 2013. https://dx.doi.org/10.1039/C3NR00476G

SHAO, F.; XU, C.; JI, W.; DONG, H.; SUN, Q.; YU, L.; DONG, L. Layer-by-layer selfassembly TiO 2 and graphene oxide on polyamide reverse osmosis membranes with improved membrane durability. Desalination, v. 423, p. 21-29, 2017. https://doi.org/10.1016/j.desal.2017.09.007

SMITH, B. C. Group Wavenumbers and an Introduction to the Spectroscopy of Benzene Rings. Spectroscopy, v. 31, n. 3, p. 34-37, 2016.

TAVARES, C.; MARQUES, S.; LANCEROS-MÉNDEZ, S.; REBOUTA, L.; ALVES, E.; BARRADAS, N.; MUNNIK, F.; GIRARDEAU, T.; RIVIÈRE, J.-P. N-doped photocatalytic titania thin films on active polymer substrates. Journal of Nanoscience $\begin{array}{lllllll}\text { and Nanotechnology, } & \text { v. 10, n. } 2010 .\end{array}$ https://doi.org/10.1166/jnn.2010.1868

VATANPOUR, V.; MADAENI, S. S.; KHATAEE, A. R.; SALEHI, E.; ZINADINI, S.; MONFARED, H. A. $\mathrm{TiO}_{2}$ embedded mixed matrix PES nanocomposite membranes: Influence of different sizes and types of nanoparticles on antifouling and performance.

Desalination, v. 292, p. 19-29, 2012. https://doi.org/10.1016/j.desal.2012.02.006

VERLIEFDE, A. R. D.; CORNELISSEN, E. R.; HEIJMAN, S. G. J.; HOEK, E. M. V.; AMY, G. L.; BRUGGEN, B. V. D.; VAN DIJK, J. C. Influence of Solute-Membrane Affinity on Rejection of Uncharged Organic Solutes by Nanofiltration Membranes. Environmental Science \& Technology, v. 43, n. 7, p. 2400-2406, 2009. https://dx.doi.org/10.1021/es803146r

XIAOXIAO, S.; JA, P.; SUN, D. D. Relating Water/Solute Permeability Coefficients to the Performance of Thin-Film Nanofiber Composite Forward Osmosis Membrane. Journal of Membrane Science \& Technology, v. $\quad 6, \quad$ n. $\quad 4, \quad$ p. $1-10,2016$. https://dx.doi.org/10.4172/2155-9589.1000167

YAMASHITA, H.; NAKAO, H.; TAKEUCHI, M.; NAKATANI, Y.; ANPO, M. Coating of $\mathrm{TiO}_{2}$ photocatalysts on super-hydrophobic porous teflon membrane by an ion assisted deposition method and their self-cleaning performance. Nuclear Instruments and Methods in Physics Research Section B: Beam Interactions with Materials and Atoms, v. 206, p. 898-901, 2003. https://doi.org/10.1016/S0168-583X(03)00895-4 
YOU, S.-J.; SEMBLANTE, G. U.; LU, S.-C.; DAMODAR, R. A.; WEI, T.-C. Evaluation of the antifouling and photocatalytic properties of poly (vinylidene fluoride) plasma-grafted poly (acrylic acid) membrane with self-assembled $\mathrm{TiO} 2$. Journal of Hazardous Materials, v. 237, p. 10-19, 2012. https://doi.org/10.1016/j.jhazmat.2012.07.071

YU, J.; WANG, G.; CHENG, B.; ZHOU, M. Effects of hydrothermal temperature and time on the photocatalytic activity and microstructures of bimodal mesoporous $\mathrm{TiO} 2$ powders. Applied Catalysis B: Environmental, v. 69, n. 3, p. 171-180, 2007. https://doi.org/10.1016/j.apcatb.2006.06.022 